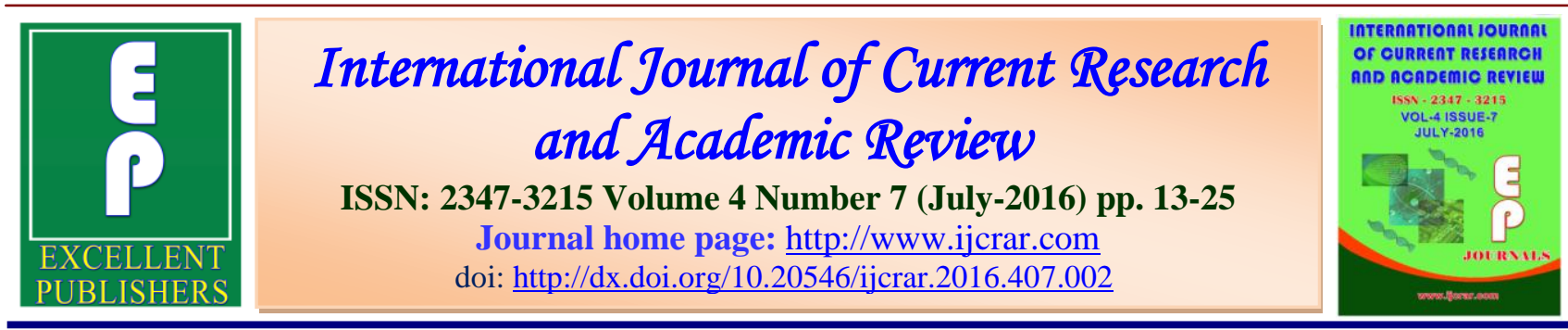

\title{
Anti-Asthmatic, Anti-Inflammatory and Antioxidant Activity of Ethanolic and Hot Water Extract of the Rhizomes of the Plant Alpinia calcarata
}

\author{
Mathew George, Lincy Joseph, K. Sujith and H. Hafees* \\ Pushpagiri College of Pharmacy, Tiruvalla, Kerala, India \\ *Corresponding author
}

\section{KEYWORDS}

Alpinia calcarata, anti-asthmatic, anti-inflammatory, anti-oxidant.

\begin{abstract}
A B S T T R A C T
The aim of the paper is to evaluate the anti-asthmatic, anti-inflammatory and anti-oxidant activity of the plant Alpinia calcarata rhizomes. In vivo antiasthamtic studies are done by histamine induced bronchoconstriction in guinea pigs and also done by milk induced leukocytosis and eosinophilia. The anti-inflammatory studies are done by protein denaturation and rabbit red blood cell membrane stabilization method. Anti-oxidant studies are done by hydrogen peroxide scavenging and reducing power assay. The ethanolic and hot water extract of the plant rhizomes are used for the study.Primary phytochemical screening of the ethanolic extract plant revealed the presence of carbohydrate, reducing sugar, alkaloid, flavonoids and phenolic compounds. The hot water extract of the plant rhizomes revealed the presence the alkaloid, flavonoid, carbohydrate and phenolic compound. Alpinia calcarata Roscoe (Family: Zingiberaceae), it is a rhizomatous perennialherb, which is commonly used in the traditional medicinal systems in Sri Lanka. Alpinia calcarata is cultivated in tropical countries, including india, Srilanka and Malaysia. Experimentally, rhizomes of Alpinia calcarata are shown to possess antibacterial, antifungal, anthelmintic, antinociceptive, antiinflammatory, antioxidant, aphrodisiac, gastro protective, and antidiabetic activities.
\end{abstract}

\section{Introduction}

This research article emphasizes on traditionally used clinically potential plant Alpinia calcarata roscoe. Alpinia calcarata Roscoe (Zingiberaceae) is a rhizomatous plant widely used as systemic medicinal sources in Sri Lanka. The mature rhizomes are branched and dense with a light to dark brown color. The leaf of the plant is simple, alternative, $25-32 \mathrm{~cm}$ long, $2.5-5 \mathrm{~cm}$ broad. The flowers are irregular, bisexual and pendanculate. Terminal densed flowers are found in panicles $8.5 \mathrm{~cm}$ long. A. calcarata is cultivated in tropical countries including India, Sri Lanka and Malaysia. 


\section{Plant Description}

Rhizomatous perennial herb with a nontuberous rootstock, stems slender, about $75 \mathrm{~cm}$ tall; leaves simple, alternate, 25-32 $\mathrm{cm}$ long and 2.5-5 broad, lanceolate, acuminate, long-pointed, glabrous on both surfaces and shining on the upper surface, scantily hairy along the margin, petioles sheathing; flowers pinkish white, irregular, bisexual, in pendunculate, terminal, dense flowered panicles $8.5 \mathrm{~cm}$ long, two flowers together at each node, one opening earlier than the other, each bearing a pair ofbracteoles, the inner one smaller than the outer, bracteoles oblong, papery white, each flower about $4 \mathrm{~cm}$ long, pedicels short, hairy; sepals 3, fused into a campanulate tube $1 \mathrm{~cm}$ long, pubescent outside, glabrous inside, apices rounded; petals 3 , fused at base but segments free tinged with pink, segments oblong-spathulate, pubescent outside, lateral narrow; staminodes 3, fused at base with the stamen into a tube adnate to corolla, two basal staminodes reduced to minute filaments, the larger one petaloid, $3 \mathrm{~cm}$ by $2.3 \mathrm{~cm}$ ovale, yellow with vinous red streaks, emarginated, apex frilled and darker, glabrous and shining on both surfaces; stamen J, anther tubular, style passing through, filament flat, $1.5 \mathrm{~cm}$ long, anther $0.8 \mathrm{~cm}$ long, style $3.5 \mathrm{~cm}$ long, tinged pink, hairy towards the apex, stigma swollen; ovary inferior, $3 \mathrm{~mm}$ long, strongly pubescent, 3-locular with ovules in each loculus on a central axis, capsules not seen.This study evaluate the antiasthmatic,anti-inflammatory and antioxidant activity of the plant.

\section{Materials and Methods}

Plant material: The plant was collected from pathanamthitta district and plant material was authenticated by Dr kavitha department of botany, specimen no: 106
Preparation of extract: Rhizomes of the plant were air dehydrated and crinkled into powdered form. The crushed powder was extracted with $70 \%$ ethanolin soxhlet apparatus. The ethanolic extract was stored in $5^{\circ} \mathrm{c}$ to get viscous mass. Also hot water extract was also prepared. Fresh Alpinia calcarata rhizomes were cut in to small pieces and air dried for 5-6 days and were boiled for 4 hour with distilled water.

Experimental animals: Guinea pig of either sex weighing 180-350 gm and albino mice of either sex 25-40 gm and albino rats rats weighing 120-180 are used for the study

Acute toxicity studies: Acute toxicity studies were implemented on Albino rats of either sex selected by sampling technique. The animals were fasted for $4 \mathrm{hrs}$ with free access to water only. The ethanolic extract of Alpinia calcarata was administered orally with varying doses. The mortality was experimented for three days. If mortality was observed in $2 / 3$ or $3 / 3$ of animals, then dose administered was considered as a toxic dose. However, if the mortality was observed in one rat out of three animals then the same dose was repetitive to confirm the toxic effect. If mortality was not observed, then procedure repeated with higher doses.

\section{Anti-inflammatory Activity}

\section{Protein-denaturation method}

A solution of $0.2 \% \mathrm{w} / \mathrm{v}$ of BSA was prepared in a Tris Buffer Saline and $\mathrm{pH}$ was adjusted to 6.8 using glacial acetic acid .Test drug of $100 \mu \mathrm{g} / \mathrm{ml}$ conc. was prepared using ethanol as solvent. $50 \mu 1(0.05 \mathrm{ml})$ of each extract was transferred to test tubes using $1 \mathrm{ml}$ micropipette. $5 \mathrm{ml}$ of $0.2 \% \mathrm{w} / \mathrm{v}$ BSA was added to the entire above test tubes. The control consists of $5 \mathrm{ml}$ of $0.2 \%$ w/v BSA solution with $50 \mu \mathrm{l}$ of alcohol. The test tubes 
were heated at $72^{\circ} \mathrm{C}$ for 5 minutes and then cooled for 10 minutes. The absorbance of these solutions was determined by using a UV-VIS Double beam spectrophotometer (ELICO SL 244) at a wavelength of $660 \mathrm{~nm}$. Each experiment was carried out in triplicate and the mean absorbance was recorded. The percentage of inhibition of precipitation was determined on a percentage basis relative to control using the formula.

Percentage of inhibition of denaturation=

absorbance of control - absorbance of sample absorbance of control

\section{The Rabbit Red Blood Cells (RRBC) Membrane Stabilization Method}

\section{Preparation of red blood cells suspension (RBC suspension)}

The fresh whole blood rabbit blood $(5 \mathrm{ml})$ was collected from the marginal ear vein to syringe containing sodium citrate to prevent clotting. The tubes were centrifuged at 3000 rpm for 10 minutes and were washed three times with equal volume of normal saline the volume of the blood was measured and reconstituted as $10 \% \mathrm{v} / \mathrm{v}$ suspension with normal saline .

\section{Membrane Stabilization Test By Hyotencicity-Induced Haemolysis}

The reaction mixture consists of $1 \mathrm{ml}$ of test sample of different concentration $(25,50,100,200,400)$ in normal saline and $0.5 \mathrm{ml}$ of $10 \% \mathrm{RBC}$ suspension , $1 \mathrm{ml}$ of 0.2 $\mathrm{M}$ phosphate buffer ,1 $\mathrm{ml}$ hypo saline were incubated at $37 \mathrm{c}$ for 30 minutes and centrifuged at $3000 \mathrm{rpm}$ for 20 minutes and the haemoglobin content of the supernatant solution was estimated spectrometrically at $560 \mathrm{~nm}$. Diclofenac sodium was used as standard and a control was prepared without extract the percentage of RBC haemolysis and membrane stabilization or protection was calculated by using the formula

$\%$ Haemolysis=

$\left(\frac{\text { optical density of test sample }}{\text { optical density of control }}\right) \times 100$

$\%$ PROTECTION $=100-\%$ haemolysis

\section{Antioxidant Activity}

\section{Hydrogen-Peroxide Scavenging Assay}

A solution of hydrogen peroxide $(40 \mathrm{mM})$ was prepared in phosphate buffer $(\mathrm{pH} 7.4)$. Extracts $(100 \mu \mathrm{g} / \mathrm{mL})$ in distilled water were added to a hydrogen peroxide solution (0.6 $\mathrm{mL}, 40 \mathrm{mM})$. Absorbance of hydrogen peroxide at $230 \mathrm{~nm}$ was determined 10 minutes later against a blank solution containing the phosphate buffer without hydrogen peroxide. The percentage of hydrogen peroxide scavenging of both PLANT extracts and standard compounds were calculated:

$$
\begin{aligned}
& \% \text { Scavenged }[\mathrm{H} 2 \mathrm{O} 2]= \\
& {[(\mathrm{AC}-\mathrm{AS}) / \mathrm{AC}] \times 100}
\end{aligned}
$$

Where AC is the absorbance of the control and AS is the absorbance in the presence of the sample

\section{Reducing Power Assay}

The reducing power of the extract was determined by the method $.1 \mathrm{ml}$ of the extract solution $(25,50,100,200$ and 400$)$ was mixed with 2.5 mlphosphate buffer $(0.2$ $\mathrm{M}, \mathrm{PH} 6.6$ ) AND 2.5 ML of potassium ferricyanide $(\mathrm{k} 2 \mathrm{fe}(\mathrm{cn}) 6) 10 \mathrm{~g} / \mathrm{l}$. then the mixture was incubated at $50 \mathrm{c}$ for 20 minutes.A portion $(2.5 \mathrm{ml})$ of trichloro 
acetic acid (15\%) was added to the mixture, which was then centrifuged at $3000 \mathrm{rpm}$ for 10 minutes. Finally $2.5 \mathrm{ml}$ of the supernatant solution was mixed with $2.5 \mathrm{ml}$ of distilled water alnd $0.5 \mathrm{ml}$ ferric chloride (Fecl3, $0.1 \%$ ) and absorbance was measured at 700 $\mathrm{nm}$ in uv visible spectrophoptometer. The experiments were performed in triplicate. Increased absorbance of the reaction mixture indicates stronger reducing power.

\section{Invivo anti ashmatic study}

Milk induced leukocytosis and eosinophilia

Mice were divided into five groups with six in each group. Blood samples were collected from retro-orbital plexus. Group I served as control and received carboxy methyl cellulose solution, groups II-IV received EAPL at (100-150 mg/kg i.p.), group V received dexamethasone at $50 \mathrm{mg} / \mathrm{kg}$ i.p. All the groups injected boiled and cooled milk (4 $\mathrm{mL} / \mathrm{kg}$, s.c.) $30 \mathrm{~min}$ after treatments. Total leukocyte and eosinophile count was done in each group before administration of test compound and $24 \mathrm{~h}$ after milk injection. Difference in total leukocytes and eosinophile count before and after $24 \mathrm{~h}$ drug administration was calculated

\section{Histamine aerosol induced broncho- constriction in guinea pigs (in-vivo)}

Histamine was dissolved in distilled water to prepare $0.2 \% \mathrm{w} / \mathrm{v}$ solution. Experimentally bronchial asthma was induced in guinea pigs by exposing histamine aerosol by an ultrasound nebulizer in an aerosol chamber $(30 \mathrm{x}$ $15 \times 15 \mathrm{~cm}$ ) made of Perspex glass. The required time for appearance of preconvulsive dyspnoea produced by the histamine was noted for each animal. Each animal was placed in the histamine chamber and exposed to $0.2 \%$ histamine aerosol. The preconvulsion time (PCT), i.e. the time of aerosol exposure to the start of dyspnoea leading to the appearance of convulsion, was noted. As quickly as the preconvulsion dyspnoea (PCD) was recorded, the animals were removed from the chamber and positioned in fresh air for recover. This time for preconvulsive dyspnoea was recorded as basal value. Guinea pigs were then allowed to recover from dyspnoea for 2 days. After that, the animals were allotted to four different groups of 4-5 animals per group. Animals in group 1 served as control and received distilled water. The animals of group 2 and 3 were given, by oral intubation, 200 and $500 \mathrm{mg} / \mathrm{kg}$ of the plant extract, respectively, while group 4 received the standard drug - Chlorpheniramine maleate, intraperitoneally. After receiving the drugs, all the animals were again exposed to histamine aerosol in the chamber, one hour, four hours and $24 \mathrm{hrs}$, to determine pre convulsive time (PCT).

\section{Results and Discussion}

\section{Anti-inflammatory}

\section{Inhibition of protein denaturation}

Denaturation of proteins is a well documented cause of inflammation. As part of the investigation on the mechanism of the anti-inflammation activity, ability of different solvent plant extract protein denaturation was studied. It was effective in inhibiting heat induced protein denaturation. Diclofenac sodium a standard antiinflammatory agent posses maximum $\%$ inhibition 91.6 at concentration $400 \mu \mathrm{g} / \mathrm{ml}$. The ethanolic and hot water extract of the plant Alpinia calcarata rhizomes posses significant $\%$ inhibition activity at concentration $200 \mu \mathrm{g} / \mathrm{ml}$ and $400 \mu \mathrm{g} / \mathrm{ml}$.So the plant posses significant antiinflammatory activity at that concentration 
Int.J.Curr.Res.Aca.Rev.2016; 4(7): 13-25

Table.1 Ethanolic extract of the plant Alpinia calcarata rhizomes

\begin{tabular}{|l|l|l|l|}
\hline $\mathrm{S}$ & Concentrat & Absorbanc & $\begin{array}{l}\% \\
\text { inhibitio } \\
\mathrm{l} \\
\mathrm{n}\end{array}$ \\
$\mathrm{i}$ & & & \\
\hline 1 & 25 & $1.28 \pm 0.05$ & 14 \\
\hline 2 & 50 & $0.578 \pm 0.03$ & 61.6 \\
\hline 3 & 100 & $0.382 \pm 0.002$ & 74.63 \\
\hline 4 & 200 & $0.189 \pm 0.01$ & 87.4 \\
\hline 5 & 400 & $0.172 \pm 0.002$ & 88.57 \\
\hline
\end{tabular}

Table.2 Hot water extract of the plant Alpinia calcarata rhizomes

\begin{tabular}{|l|l|l|l|}
\hline $\begin{array}{l}\text { S1 } \\
\text { no }\end{array}$ & Concentration & absorbance & $\%$ inhibition \\
\hline 1 & 25 & $1.38 \pm 0.04$ & 8.36 \\
\hline 2 & 50 & $0.656 \pm 0.03$ & 56.3 \\
\hline 3 & 100 & $0.568 \pm 0.001$ & 62.2 \\
\hline 4 & 200 & $0.289 \pm 0.002$ & 80.2 \\
\hline 5 & 400 & $0.188 \pm 0.001$ & 87.5 \\
\hline
\end{tabular}

Table.3 Standard (diclofenac sodium)

\begin{tabular}{|l|l|l|l|}
\hline $\begin{array}{l}\text { S1 } \\
\text { no }\end{array}$ & Concentration & absorbance & \% inhibition \\
\hline 1 & 25 & $0.854 \pm 0.02$ & 43.2 \\
\hline 2 & 50 & $0.578 \pm 0.002$ & 61.6 \\
\hline 3 & 100 & $0.434 \pm .0 .001$ & 70.8 \\
\hline 4 & 200 & $0.289 \pm 0.002$ & 80.8 \\
\hline 5 & 400 & $0.133 \pm 0.121$ & 91.6 \\
\hline
\end{tabular}

Fig.1 Inhibition of protein denaturation

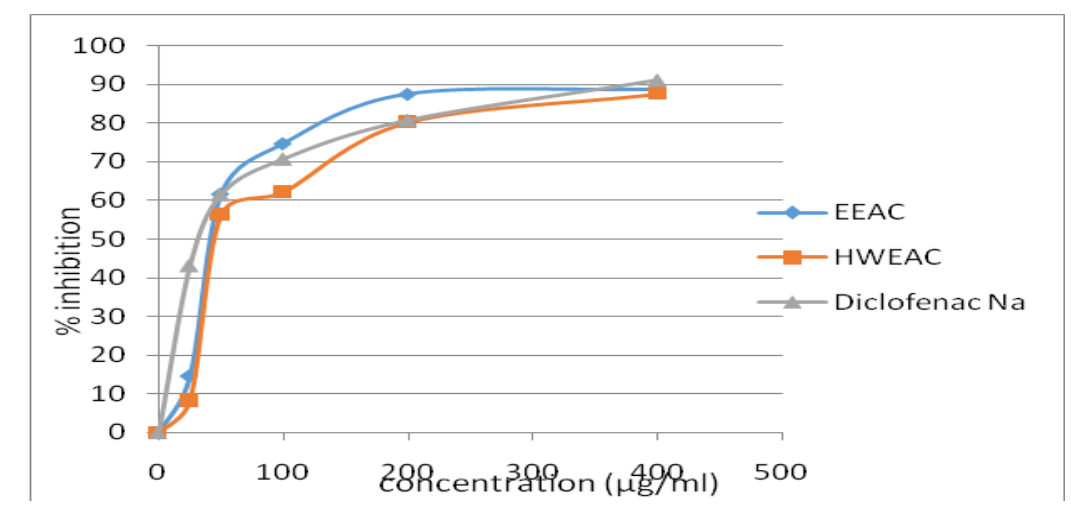


Int.J.Curr.Res.Aca.Rev.2016; 4(7): 13-25

Table.4 Ethanolic extract of the plant Alpinia calcarata rhizomes

\begin{tabular}{|l|l|l|l|}
\hline S1 no & Concentration & Absorbance & \% inhibition \\
\hline 1 & 25 & $0.632 \pm 0.0005$ & 17.16 \\
\hline 2 & 50 & $0.539 \pm 0.00052$ & 29.5 \\
\hline 3 & 100 & $0.474 \pm 0.0056$ & 38.04 \\
\hline 4 & 200 & $0.414 \pm 0.0005$ & 46 \\
\hline 5 & 400 & $0.357 \pm 0.00056$ & 53.3 \\
\hline
\end{tabular}

Table.5 Hot water extract of the plant Alpinia calcarata rhizome

\begin{tabular}{|l|l|l|l|}
\hline S1 no & Concentration & Absorbance & \% inhibition \\
\hline 1 & 25 & $0.648 \pm 0.004$ & 15.09 \\
\hline 2 & 50 & $0.554 \pm 0.0003$ & 27.4 \\
\hline 3 & 100 & $0.488 \pm 0.002$ & 36.05 \\
\hline 4 & 200 & $0.438 \pm 0.003$ & 42.6 \\
\hline 5 & 400 & $0.386 \pm 0.0023$ & 49 \\
\hline
\end{tabular}

Table.6 Standard (hydrogen peroxide)

\begin{tabular}{|l|l|l|l|}
\hline Sl no & Concentration & Absorbance & \% inhibition \\
\hline 1 & 25 & $0.568 \pm 0.003$ & 25.5 \\
\hline 2 & 50 & $0.489 \pm 0.002$ & 36.9 \\
\hline 3 & 100 & $0.388 \pm 0.004$ & 49.16 \\
\hline 4 & 200 & $0.355 \pm 0.001$ & 53.5 \\
\hline 5 & 400 & $0.312 \pm 0.004$ & 58.4 \\
\hline
\end{tabular}

Fig.2 Membrane stabilization method

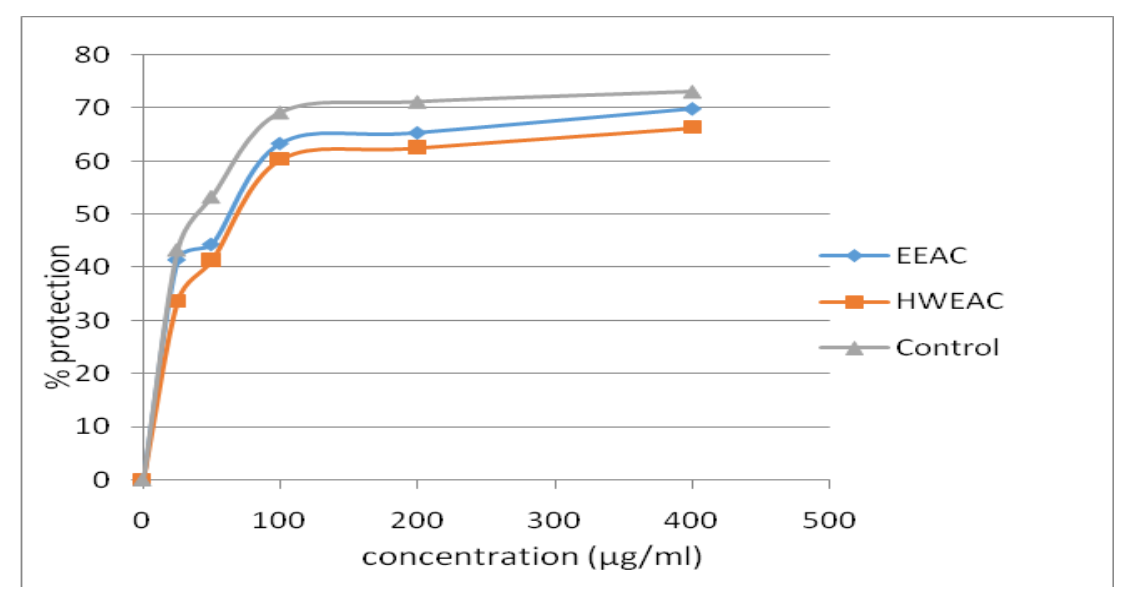


Int.J.Curr.Res.Aca.Rev.2016; 4(7): 13-25

Rabbit red blood cell membrane stabilization method

$\%$ protection of each samples are calculated. Standard drug diclofenac sodium show significant $\%$ protection. The hot water and ethanolic extract of the plant at concentration 200 and $400 \mu \mathrm{g} / \mathrm{ml}$ show significant $\%$ protection. The plant Alpinia calcarata rhizomes posses significant antiinflammatory activity

\section{Antioxidant activity}

\section{Hydrogen peroxide scavenging activity}

The scavenging ability of hot water and ethanol extracts of Alpinia calcarata on hydrogen peroxide was studied by using ascorbic acid as standard. The rhizomes of the plant extracts were capable of scavenging hydrogen peroxide in an amount dependent manner. $100 \mu \mathrm{g} / \mathrm{ml}$ of hot water and ethanol extracts of the plant exhibited $36.05 \%$ and $38.04 \%$ scavenging activity on hydrogen peroxide. On the other hand, using the same amounts standard drug exhibited $49.16 \%$ hydrogen peroxide scavenging activity. Also plant extract of ethanol and hot water at concentration $400 \mu \mathrm{g} / \mathrm{ml}$ posses 53 and $49 \%$ scavenging activity.The standard drug posses $58.4 \%$ scavenging activity.The plant Alpinia calcarata rhizomes posses significant activity.

Table.7 Ethanolic extract of the plant Alpinia calcarata rhizomes

\begin{tabular}{|l|l|l|l|}
\hline Sl no & Concentration & Absorbance & \% inhibition \\
\hline 1 & 25 & $0.632 \pm 0.0005$ & 17.16 \\
\hline 2 & 50 & $0.539 \pm 0.00052$ & 29.5 \\
\hline 3 & 100 & $0.474 \pm 0.0056$ & 38.04 \\
\hline 4 & 200 & $0.414 \pm 0.0005$ & 46 \\
\hline 5 & 400 & $0.357 \pm 0.00056$ & 53.3 \\
\hline
\end{tabular}

Table. 8 Hot water extract of the plant Alpinia calcarata rhizome

\begin{tabular}{|l|l|l|l|}
\hline Sl no & Concentration & Absorbance & \% inhibition \\
\hline 1 & 25 & $0.648 \pm 0.004$ & 15.09 \\
\hline 2 & 50 & $0.554 \pm 0.0003$ & 27.4 \\
\hline 3 & 100 & $0.488 \pm 0.002$ & 36.05 \\
\hline 4 & 200 & $0.438 \pm 0.003$ & 42.6 \\
\hline 5 & 400 & $0.386 \pm 0.0023$ & 49 \\
\hline
\end{tabular}

Table.9 Standard (hydrogen peroxide)

\begin{tabular}{|l|l|l|l|}
\hline S1 no & Concentration & Absorbance & \% inhibition \\
\hline 1 & 25 & $0.568 \pm 0.003$ & 25.5 \\
\hline 2 & 50 & $0.489 \pm 0.002$ & 36.9 \\
\hline 3 & 100 & $0.388 \pm 0.004$ & 49.16 \\
\hline 4 & 200 & $0.355 \pm 0.001$ & 53.5 \\
\hline 5 & 400 & $0.312 \pm 0.004$ & 58.4 \\
\hline
\end{tabular}


Int.J.Curr.Res.Aca.Rev.2016; 4(7): 13-25

Fig.3 Hydrogen peroxide sacavenging assay

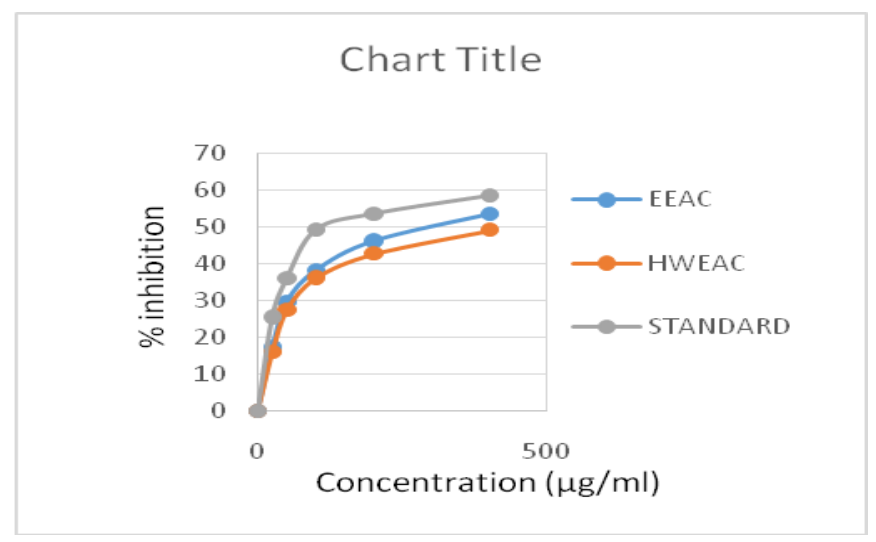

Table.10 Ethanolic extract of the plant Alpinia calcarata rhizomes

\begin{tabular}{|l|l|l|}
\hline $\begin{array}{l}\text { S1 } \\
\text { no }\end{array}$ & Concentration & Absorbance \\
\hline 1 & 25 & $0.782 \pm 0.32$ \\
\hline 2 & 50 & $0.891 \pm 0.41$ \\
\hline 3 & 100 & $1.3 \pm 0.32$ \\
\hline 4 & 200 & $1.4 \pm 0.42$ \\
\hline 5 & 400 & $1.56 \pm 0.82$ \\
\hline
\end{tabular}

Table.11 Hot water extract of the plant Alpinia calcarata rhizome

\begin{tabular}{|l|l|l|}
\hline $\begin{array}{l}\text { Sl } \\
\text { no }\end{array}$ & Concentration & Absorbance \\
\hline 1 & 25 & $0.713 \pm 0.24$ \\
\hline 2 & 50 & $0.783 \pm 0.31$ \\
\hline 3 & 100 & $0.812 \pm 0.12$ \\
\hline 4 & 200 & $1.1 \pm 0.22$ \\
\hline 5 & 400 & $1.3 \pm 0.21$ \\
\hline
\end{tabular}

Fig.4 Reducing power asssay

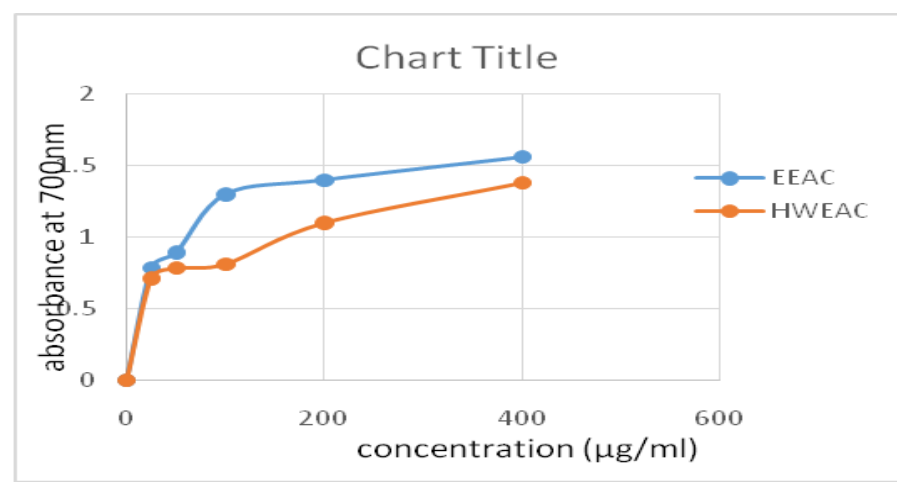


Int.J.Curr.Res.Aca.Rev.2016; 4(7): 13-25

Table.12 Effect of rhizomes of Alpinia calcarata on histamine induced bronchoconstriction in guinea pig

\begin{tabular}{|l|l|l|l|l|}
\hline \multirow{2}{*}{ Group } & \multicolumn{3}{|c|}{ Latent period of convulsion } & \multicolumn{1}{c|}{$24 \mathrm{hr}$} \\
\cline { 2 - 5 } & \multicolumn{1}{|c|}{ Before } & $1 \mathrm{hr}$ & $4 \mathrm{hr}$ & $36.5 \pm 0.06$ \\
\hline $\begin{array}{l}\text { Chlorephenaramine maleate } \\
(1 \mathrm{mg} / \mathrm{kg})\end{array}$ & $18.46 \pm 0.08$ & $60.2 \pm 0.05$ & $68.2 \pm 0.01$ & $28.2 \pm 0.003$ \\
\hline $\begin{array}{l}\text { Alpinia calcarata } \text { ethanolic } \\
\text { extract(100 mg/kg) }\end{array}$ & $16.71 \pm 0.06$ & $29.6 \pm 0.04$ & $39.3 \pm 0.03$ & $28.4 \pm 0.001$ \\
\hline $\begin{array}{l}\text { Alpinia calcarata } \text { ethanolic } \\
\text { extract(200 mg/kg) }\end{array}$ & $15.71 \pm 0.06$ & $30.5 \pm 0.06$ & $40.3 \pm 0.04$ & $28.6 \pm 0.06$ \\
\hline $\begin{array}{l}\text { Alpinia calcarata hot water } \\
\text { extract }(100 \mathrm{mg} / \mathrm{kg})\end{array}$ & $16.45 \pm 0.07$ & $27.6 \pm 0.01$ & $36 \pm 0.05$ & $29.6 \pm 0.04$ \\
\hline $\begin{array}{l}\text { Alpinia calcarata } \text { hot water } \\
\text { extract(200 mg/kg) }\end{array}$ & $16.9 \pm 0.06$ & $29.6 \pm 0.06$ & $39 \pm 0.01$ & $18.4 \pm 0.002$ \\
\hline Control( carboxy methyl cellulose & $16.3 \pm 0.02$ & $18.3 \pm 0.05$ & $18.6 \pm 0.05$ & \\
\hline
\end{tabular}

Table.13 Effect of rhizomes of Alpinia calcarata on histamine induced bronchoconstriction in guinea pig

\begin{tabular}{|l|l|l|l|l|}
\hline \multirow{2}{*}{ Group } & \multicolumn{3}{|c|}{ Latent period of convulsion } \\
\cline { 2 - 5 } & Before & $1 \mathrm{hr}$ & $4 \mathrm{hr}$ & $24 \mathrm{hr}$ \\
\hline $\begin{array}{l}\text { Chlorephenaramine maleate(1 } \\
\mathrm{mg} / \mathrm{kg} \text { ) }\end{array}$ & $18.46 \pm 0.08$ & $60.2 \pm 0.05$ & $68.2 \pm 0.01$ & $36.5 \pm 0.06$ \\
\hline $\begin{array}{l}\text { Alpinia calcarata } \text { ethanolic } \\
\text { extract(100 mg/kg) }\end{array}$ & $16.71 \pm 0.06$ & $29.6 \pm 0.04$ & $39.3 \pm 0.03$ & $28.2 \pm 0.003$ \\
\hline $\begin{array}{l}\text { Alpinia calcarata } \text { ethanolic } \\
\text { extract(200 mg/kg) }\end{array}$ & $15.71 \pm 0.06$ & $30.5 \pm 0.06$ & $40.3 \pm 0.04$ & $28.4 \pm 0.001$ \\
\hline $\begin{array}{l}\text { Alpinia calcarata } \text { hot water } \\
\text { extract(100 mg/kg) }\end{array}$ & $16.45 \pm 0.07$ & $27.6 \pm 0.01$ & $36 \pm 0.05$ & $28.6 \pm 0.06$ \\
\hline $\begin{array}{l}\text { Alpinia calcarata hot water } \\
\text { extract(200 mg/kg) }\end{array}$ & $16.9 \pm 0.06$ & $29.6 \pm 0.06$ & $39 \pm 0.01$ & $29.6 \pm 0.04$ \\
\hline Control( carboxy methyl cellulose & $16.3 \pm 0.02$ & $18.3 \pm 0.05$ & $18.6 \pm 0.05$ & $18.4 \pm 0.002$ \\
\hline
\end{tabular}

Table.14 Milk induced leukocytosis and eosinophilia

\begin{tabular}{|l|l|l|}
\hline Groups & Drug dose & $\begin{array}{l}\text { Difference in no of } \\
\text { leucocytes before and after } \\
\text { treatment(Cu.mm) }\end{array}$ \\
\hline Standard(Dexamethosone) & $50 \mathrm{mg} / \mathrm{kg}$ & $600 \pm 22$ \\
\hline Alpinia calcarata ethanolic extract & $100 \mathrm{mg} / \mathrm{kg}$ & $2580 \pm 18$ \\
\hline Alpinia calcarata ethanolic extract & $200 \mathrm{mg} / \mathrm{kg}$ & $1280 \pm 26$ \\
\hline Alpinia calcarata hot water extract & $100 \mathrm{mg} / \mathrm{kg}$ & $2920 \pm 19$ \\
\hline Alpinia calcarata hot water extract & $200 \mathrm{mg} / \mathrm{kg}$ & $1960 \pm 20$ \\
\hline Control(carboxy methyl cellulose) & $0.2 \%$ & $4100 \pm 31$ \\
\hline
\end{tabular}


Int.J.Curr.Res.Aca.Rev.2016; 4(7): 13-25

Table.15 Milk induced eosinophilia

\begin{tabular}{|l|l|l|}
\hline Groups & Drug dose & $\begin{array}{l}\text { Difference in no of } \\
\text { eosinophilic count before and } \\
\text { after treatment(Cu.mm) }\end{array}$ \\
\hline Standard(Dexamethosone) & $50 \mathrm{mg} / \mathrm{kg}$ & $38 \pm 3$ \\
\hline $\begin{array}{l}\text { Alpinia calcarata } \text { ethanolic } \\
\text { extract }\end{array}$ & $100 \mathrm{mg} / \mathrm{kg}$ & $82 \pm 5$ \\
\hline $\begin{array}{l}\text { Alpinia calcarata } \text { ethanolic } \\
\text { extract }\end{array}$ & $200 \mathrm{mg} / \mathrm{kg}$ & $53 \pm 2$ \\
\hline $\begin{array}{l}\text { Alpinia calcarata } \text { hot water } \\
\text { extract }\end{array}$ & $100 \mathrm{mg} / \mathrm{kg}$ & $91 \pm 6$ \\
\hline $\begin{array}{l}\text { Alpinia calcarata } \text { hot water } \\
\text { extract }\end{array}$ & $200 \mathrm{mg} / \mathrm{kg}$ & $64 \pm 1$ \\
\hline $\begin{array}{l}\text { Control(carboxy methyl } \\
\text { cellulose) }\end{array}$ & $0.2 \%$ & $118 \pm 12$ \\
\hline
\end{tabular}

Fig.5 latent period of convulsion

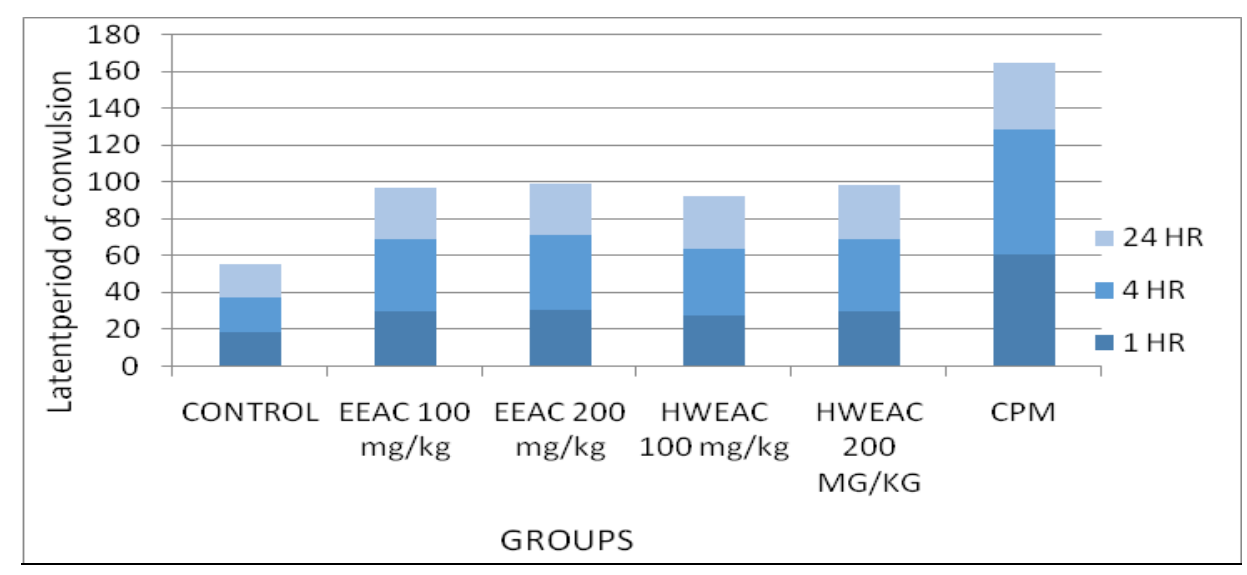

Fig.6 $\%$ protection

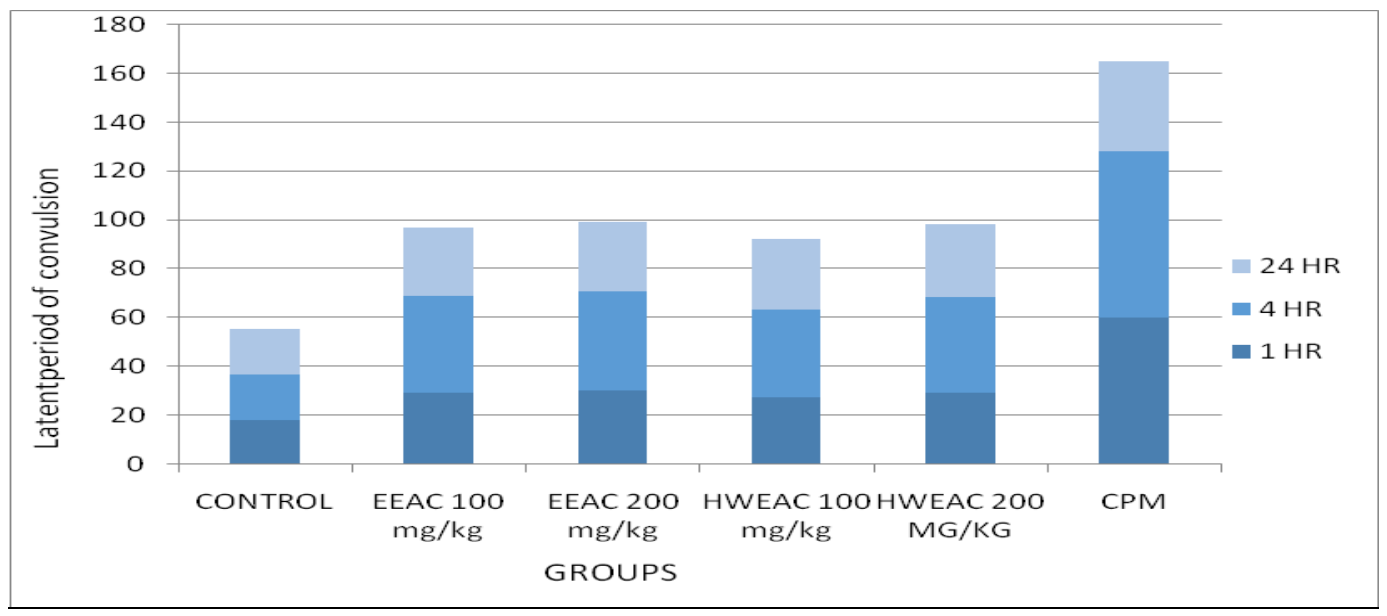


Fig.7 Difference in number of leucocytes

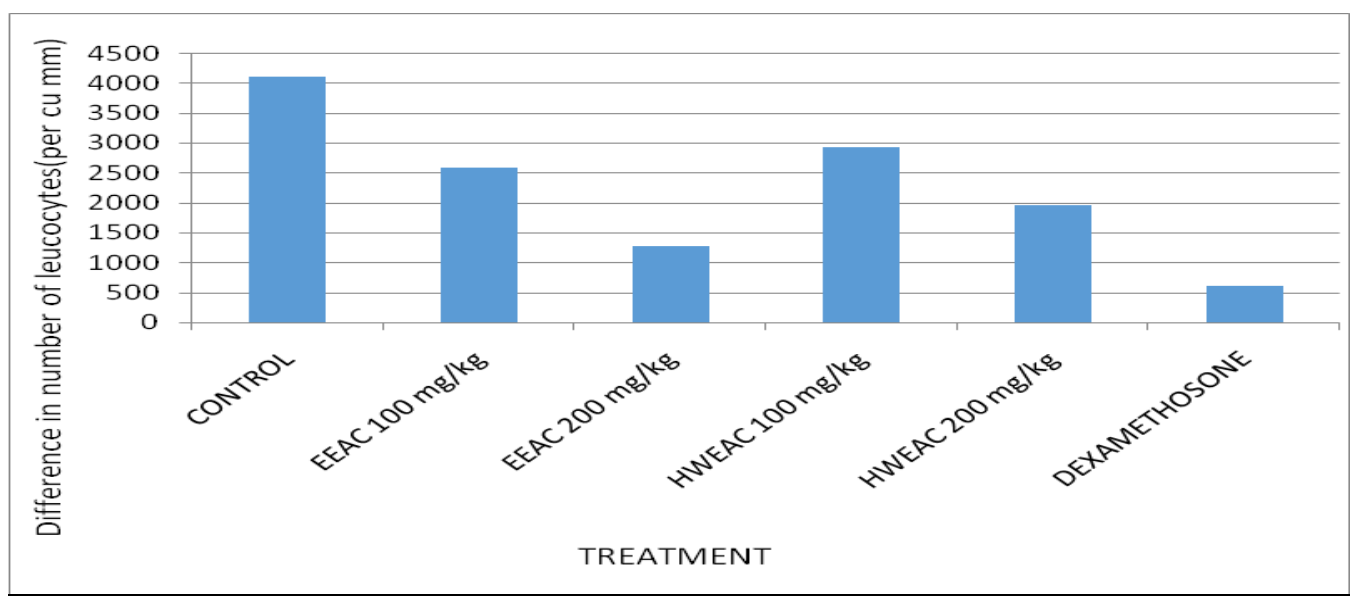

Fig.8 Difference in no of eosinophil

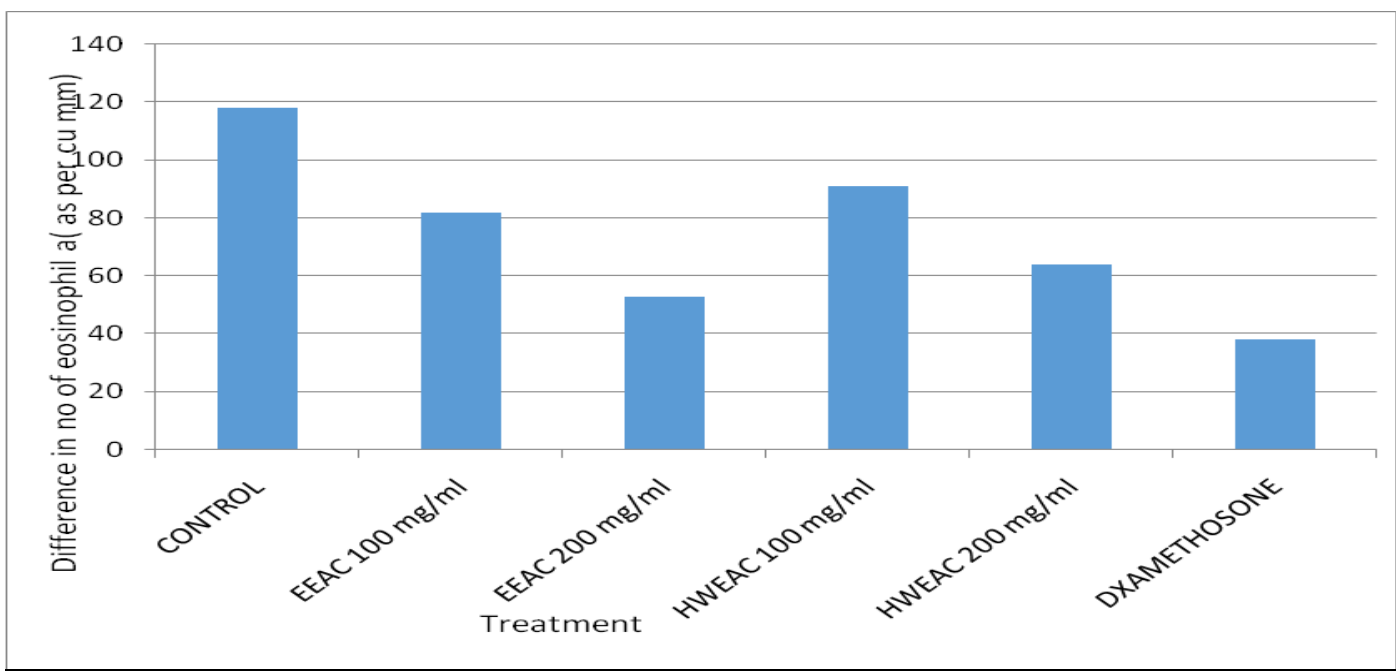

\section{Reducing power assay}

The reducing ability of the extract served as a significant indicator of its potential antioxi dant activity.The reducing power of the plant increased concentration dependently.

\section{Aniti asthmatic activity}

\section{Histamamine aerosol induced bronchoconstriction in guinea pig}

Bronchoconstriction induced by Histamine is an immunological model of antigen induced airway obstruction.
Histamine when inhaled causes hypoxia and leads to spasm in Guinea pigs and causes very strong smooth muscle contraction and capillary dilation in cardiovascular system. Bronchodilators can delay the occurrence of these symptoms.

The study resulted in deep-rooted the bronchodilator properties of the plant, justifying its claiming in the treatment of asthma. The ethanolic and hot water extract of the plant expressively extended the latent period of spasms followed by exposing to histamine aerosol at the dose $400 \mathrm{mg} / \mathrm{kg}$ which showed the protection respectively 
Int.J.Curr.Res.Aca.Rev.2016; 4(7): 13-25

60.79 and $58.56 \%$ at time 4 hour as compred to the standard drug chlorpheniramine maleate $1 \mathrm{mg} / \mathrm{kg}$ which untaken maximum protection of 73.3 at time 4 hour.

\section{Milk induced leukocytosis and eosinophilia}

Maximum increase in difference of leukocytes $(4100 \pm 31)$ and eosinophil $(118 \pm 12)$ was observed in control group. The groups of mice pretreated with 200 $\mathrm{mg} / \mathrm{kg}$ of ethanolic and hot water ectract showed significant inhibition of milk induced leukocytosis and eosinophilia as compared to the The standard drug dexamethasone.

\section{Conclusion}

Drugs effective in asthma are steroidal in nature. The plant Alpinia calcarata posses significant anti-asthmatic effect. Also the plant rhizomes posses significant antioxidant and anti-inflammatory activity

\section{References}

Arambcwela, L.S.R., et al. 2005. Report submitted to NSF on the Development of therapeutic products based on plant derived immunomodulatory and other bioactive compounds / extracts.

Arambcwela, L.S.R., Kumaratunge, A. and Arawwawela, M. 2005. Volatile oils oi'Alpinia calcarata Rose, grown in Sri Lanka. J. Essential Oil Res., 17: 124-125.

Arambewela, L.S.R., L.D.A.M. Arawwawal W.D. Ratnasooriya. 2004. Antinocice ptive activities of aqueous and ethanolic extracts of Alpinia calcarata rhizome in rats. Elsevier volume 95, issue 2-3, page 311-316.
Arambewela, $\quad$ L.S.R., $\quad$ L.D.A.M. Arawwawala, W.D. Ratnasooriya. 2012. Alpinia calcarata roscoe a potent antiinflammatory agent. $J$. Ethano-Pharmacol., vol.139 page 889-892.

Armbewela, L.S., Arawwawala, L.D. 2005. Antioxidant activities of ethanolic and hot aqueous extracts of Alpinia calcarata rhizomes, Australian J. Med. Herbalisam, volume 17 issue 3

Ayurveda Pharmacopoeia. 1976. Department of Ayurveda, Colombo, Sri Lanka. Vol. I, Pan 2.

Jayaweera, D.M.A. (19\&l). Medicinal plants (Indigenous and Exotic) used in Ceylon, National Science Council of Sri Lanka. Pan V.

Kong, L.Y., Qin, M.J. and Niwa, M. 2000. Diterpenoids from rhizomes of Alpinia calcarata. J. Natural Product, 63(7): 939-942.

Kong, L.Y., Qin, M.J. and Njwa, M. 2002. New cytotoxic bis-labanic ditcrpenoids from Alpinia calcarata. Planta Medica, 68(9): 813-817.

Kumaratunga, K.G.A. 2003. Gas chromatographic and Antimicrobial studies on Alpinia calcarata and Piper betle from Sri Lanka. M.Phil Thesis, University of Kelaniya, Sri Lanka.

Merh, P.S., Daniel, M. and Sabnis, S.D. 1986. Chemisiry and taxonomy of some members of the Zingiberales. Curr. Sci., 55(17): 835-839.

Osuturu Visitimi. 1994. Department of Auyrveda. Pan I.

Perera, D.L. (Ed.), 2003. Osn Turn Wagaluga. Sri Lanka Conservat10 and Sustainable Use of Medicinal Plants, No.4, Woodland Avenue, Kohuwala.

Pushpangadan, P., Atal, C.K. 1984. Ethnomedico-Bolanicalinvestigations in Kerala I,Some primitive tribals of Western Ghats and their herbal 
medicine. J. Ethnopharmacol., 11(1): 59-77.

Ranasingha, S.G. 1997J. Armavatayata Erehi Aratta, Clinical and Experimental Studies on AntiArthritic Property of Alpinia calcarata Rose. (Sri Lanka Rasna). S. Godage and Brothers, 676, Maradana Road, Colombo 10.

Senarathna, D.W.J. 1987. Osupala saha Atbehet, Bandaranaikc Memorial Ayurveda Research Institute.
Silvy Mathew, S., John Britto, Sinjumol, Thomas. 2004. Assesment of antimicrobial activity of Alpinia calcarata roscoe, Int. J. Pharmaceutical Innovations, vol.4, issue1.

Thalpatha Osumahhna. 2002. Department of Ayurveda, Bandaranaikc Memorial Ayurveda Research Institute. Vol. I.

\section{How to cite this article:}

Mathew George, Lincy Joseph, K. Sujith and H. Hafees. 2016. Anti-Asthmatic, AntiInflammatory and Antioxidant Activity of Ethanolic and Hot Water Extract of the Rhizomes of the Plant Alpinia calcarata. Int.J.Curr.Res.Aca.Rev.4(7): 13-25.

doi: http://dx.doi.org/10.20546/ijcrar.2016.407.002 